\title{
Secular Stagnation and Returns on Capital
}

\author{
Paul Gomme, Professor of Economics, Concordia University \\ B. Ravikumar, Vice President and Deputy Director of Research, Federal Reserve Bank of St. Louis \\ Peter Rupert, Professor of Economics, University of California, Santa Barbara
}

$\mathbf{T}$ here has been an outpouring of chat in both policy circles and the blogosphere concerning "secular stagnation." Alvin Hansen coined the term in his 1938

American Economic Association presidential address (Hansen, 1939), and Lawrence Summers (2014) resurrected it in reference to the sluggish recovery from the Great Recession. (A Google search of "secular stagnation" will provide a lifetime of reading. ${ }^{1}$ )

Hansen describes the context of the term as follows: "we must fall back upon a more rapid advance of technology than in the past if we are to find private investment opportunities adequate to maintain full employment... It is my growing conviction that the combined effect of the decline in population growth, together with the failure of any really important innovations of a magnitude sufficient to absorb large capital outlays, weighs very heavily as an explanation for the failure of the recent recovery to reach full employment."

How would a policymaker determine whether there are adequate private investment opportunities, an essential component of the secular stagnation hypothesis? One approach is to examine real interest rates. Bernanke (2015a) notes that real interest rates are "most relevant for capital investment decisions," and Summers (2015a) notes that they "are determined by broad factors bearing on the supply and demand for capital." Bernanke also says a low real interest rate would indicate that "investment opportunities are limited and relatively unprofitable" (Bernanke, 2015a); that is, it would indicate that adequate private investment opportunities are not easily available.

Some commentators have pointed to the returns on Treasury securities to evaluate private investment opportunities. For instance, Baldwin and Teulings (2014) use the overnight real interest rate and 30-year inflation-linked bonds, Bernanke (2015b) uses 5-year inflation-indexed securities, and Summers (2015b) uses 5-year 5-year forward Treasury inflation-protected securities [TIPS]).
Figure 1 shows real returns on 90-day, 3-year, and 5-year Treasury securities from 1985 to $2015 .^{2}$ While these series differ from those used by the authors noted above, they capture the same broad trends and exhibit a qualitatively similar pattern. The returns on all three Treasury securities have been declining and are currently low. ${ }^{3}$ The 5 -year return, for instance, has been close to zero recently.

\section{Returns on government debt bear little resemblance to returns on productive capital.}

In the context of the secular stagnation hypothesis, if one is interested in the return that is "most relevant for capital investment decisions," then why look at the returns on Treasury securities? Aren't the returns on productive capital more relevant for capital investment decisions than the returns on government debt?

In a recent paper (Gomme, Ravikumar, and Rupert, 2011), we examined the real returns on productive capital using National Income and Product Accounts (NIPA) data. The basic idea behind our measurement was simply to add up the income generated from capital and then divide the sum by the capital stock that generated the income. ${ }^{4}$

As shown in Figure 2, pre- and post-tax real returns on (i) business capital and (ii) all capital have not been declining. ${ }^{5}$ The returns fell during the Great Recession, as they typically do in recessions. However, the returns quickly rebounded and are now as high as they have been over the past three decades! The after-tax return on business capital is more than 8 percent now, much larger than the pre-tax 5 -year Treasury return. The after-tax return on all capital is more than 6 percent.

The evidence on returns on productive capital suggests that it is difficult to defend the idea that there is a lack of adequate private investment opportunities. A natural 


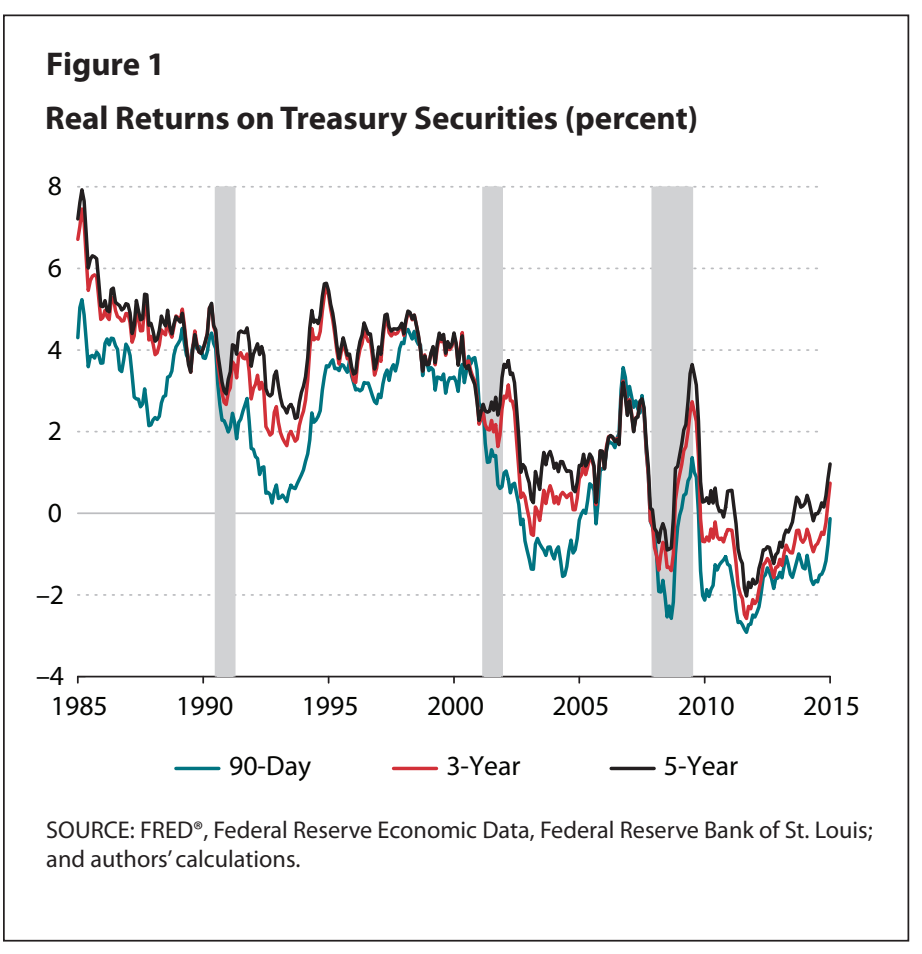

\section{Figure 3}

Real Gross Private Domestic Nonresidential Investment

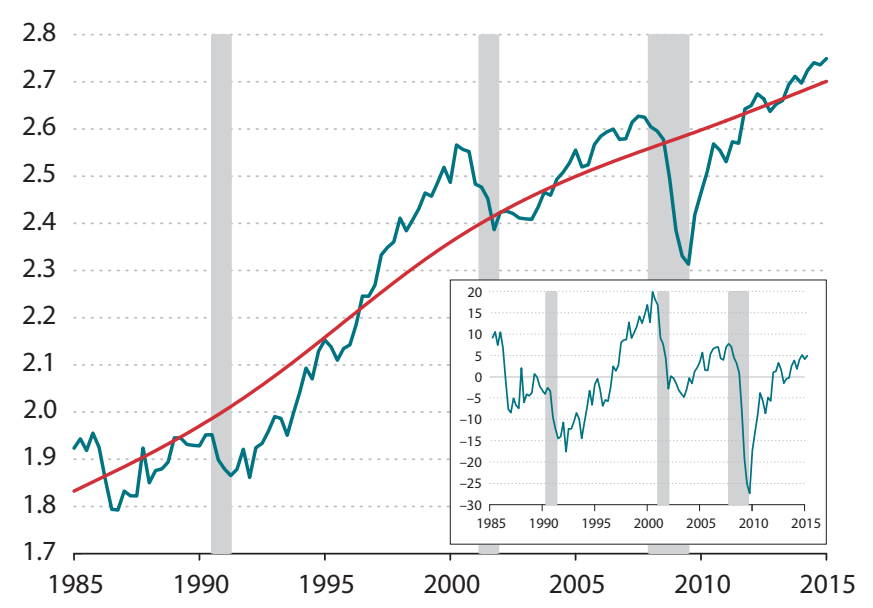

SOURCE: FRED ${ }^{\oplus}$, Federal Reserve Economic Data, Federal Reserve Bank of St. Louis; and authors' calculations.

question at this point is, why not look at the behavior of private investment? Figure 3 shows the time series on private domestic nonresidential investment. Consistent with the pattern of the real return on productive capital, private domestic nonresidential investment has been steadily increasing since the end of the recent recession. The insert in the figure shows the deviations from trend and that pri-

\section{Figure 2}

\section{Real Returns on Capital (percent)}

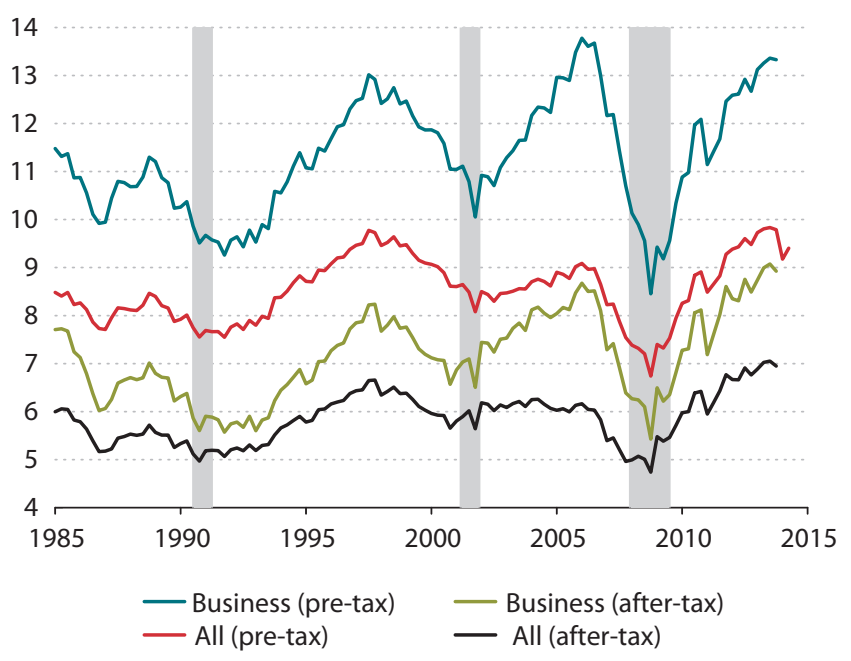

SOURCE: Authors' calculations; for details, see Gomme, Ravikumar, and Rupert (2011).

\section{Figure 4}

\section{Real Gross Private Domestic Investment}

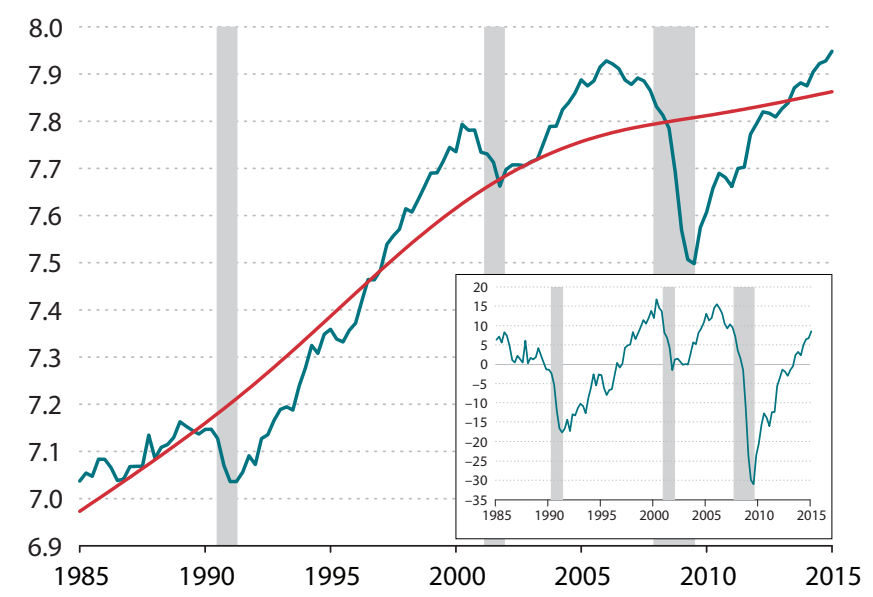

SOURCE: FRED ${ }^{\circledR}$, Federal Reserve Economic Data, Federal Reserve Bank of St. Louis; and authors' calculations.

vate nonresidential investment is now more than 5 percent above trend. Private nonresidential investment is also 14.5 percent higher than its pre-recession peak in the fourth quarter of 2007.

A similar pattern holds for all investment, a measure that includes both residential and nonresidential investment (see Figure 4). Consistent with the rising return on 
all capital after the recession, the series on all investment displays an increase. It is now more than 8 percent above trend and almost 9 percent above the peak in the fourth quarter of 2007.

While many authors have documented the low and declining returns on government debt, these returns bear little resemblance to the returns on productive capital: The latter is a direct measure and a much better indicator of adequate private investment opportunities and has been rising for the past five years. Summers (2014) and others have articulated the secular stagnation hypothesis based on insufficient aggregate demand: The evidence on investment strongly suggests otherwise. Indeed, the private sector has undertaken large capital outlays since the end of the recession.

The takeaway here is that the current recovery is not an example of secular stagnation. The evidence on investment and returns on productive capital shatter the essential components of the secular stagnation hypothesis.

\section{NOTES}

1 See, for instance, the collection of articles in Teulings and Baldwin (2014).

2 The inflation measure used is the 12-month change in the personal consumption expenditures deflator.

3 Kocherlakota (2015) also documents declining real interest rates using the 10-year 10-year forward TIPS yields.

${ }^{4}$ For example, to compute the after-tax income from business capital, use the net operating surplus data in NIPA (value added minus depreciation and payments to labor) and modify the income flows and tax rates to subtract out the income generated from the housing sector. Finally, attribute a fraction of proprietors' income to capital income (because the NIPA do not separate capital from labor income for proprietorships).

5 "Business" capital includes nonresidential fixed capital (structures, equipment, and intellectual property) and inventories. "All" capital includes business capital and residential capital.

\section{REFERENCES}

Baldwin, Richard and Teulings, Coen. "Introduction," in Coen Teulings and Richard Baldwin, eds., Secular Stagnation: Facts, Causes and Cures. CEPR Press, 2014, pp. 1-23;

http://www.voxeu.org/sites/default/files/Vox_secular_stagnation.pdf.

Bernanke, Ben. "Why Are Interest Rates So Low?" Ben Bernanke's Blog, March 30, 2015a; http://www.brookings.edu/blogs/ben-bernanke/posts/2015/03/30why-interest-rates-so-low.

Bernanke, Ben. "Why Are Interest Rates So Low, Part 2: Secular Stagnation." Ben Bernanke's Blog, March 31, 2015b; http://www.brookings.edu/blogs/benbernanke/posts/2015/03/31-why-interest-rates-low-secular-stagnation.

Gomme, Paul; Ravikumar, B. and Rupert, Peter "The Return to Capital and the Business Cycle." Review of Economic Dynamics, April 2011, 14(2), pp. 262-78; http://www.sciencedirect.com/science/article/pii/S1094202510000591.

Hansen, Alvin H. "Economic Progress and Declining Population Growth." American Economic Review, March 1939, 29(1), pp. 1-15;

http://www.jstor.org/stable/1806983?seq=5\#page_scan_tab_contents.

Kocherlakota, Narayana. "Fiscal Policy and the Long-Run Neutral Real Interest Rate." Speech at the Bundesbank Conference, Frankfurt, Germany, July 9, 2015; https://www.minneapolisfed.org/news-and-events/presidents-speeches/fiscal-policy-and-the-long-run-neutral-real-interest-rate.

Summers, Lawrence. "U.S. Economic Prospects: Secular Stagnation, Hysteresis, and the Zero Lower Bound." Business Economics, April 2014, 49(2), pp. 65-73; http://www.palgrave-journals.com/be/journal/v49/n2/pdf/be201413a.pdf.

Summers, Lawrence. "On Secular Stagnation: Larry Summers Responds to Ben Bernanke." Ben Bernanke's Blog, April 1, 2015a;

http://www.brookings.edu/blogs/ben-bernanke/posts/2015/04/01-larry-summers-response.

Summers, Lawrence. "Demand Side Secular Stagnation." American Economic Review, May 2015b, 105(5), pp. 60-65; http://pubs.aeaweb.org/doi/pdfplus/10.1257/aer.p20151103.

Teulings, Coen and Baldwin, Richard, eds. Secular Stagnation: Facts, Causes and Cures. CEPR Press, 2014;

http://www.voxeu.org/sites/default/files/Vox_secular_stagnation.pdf. 